\title{
More than a Dime's Worth: Using State Party Platforms to Assess the Degree of American Party Polarization
}

Daniel J. Coffey, University of Akron

ABSTRACT How polarized are American political parties? Recently, Kidd used an automated content analysis program to demonstrate that American party platforms reveal only minor policy differences. In contrast to his conclusions, this analysis produces three main findings. First, at the state level, state party platforms reveal considerable ideological differences between the parties. Second, differences in state public opinion do not account for these differences; rather, they are more closely correlated with activist opinions and increases in state party competition. Finally, the conflict is not simply ideological but applies to specific issues in the platforms. As such, American state parties are highly polarized on different measures. Automated content analysis programs clearly represent an important methodological advance in coding political texts, but the results here call attention to the importance of policy and agenda content in party platforms. Moreover, studies of American politics, particularly research focusing on parties and ideological polarization, need to take into account the diversity of agendas that is inherent in a federal party system.

Note. A similar version of this research appeared as a chapter in The State of the Parties: The Changing Role of Contemporary American Parties, 5th ed., by John C. Green and Daniel J. Coffey (Rowman and Littlefield, 2007).

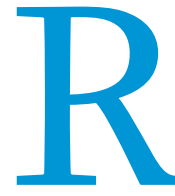

ecent methodological advances have spurred a renewed interest in party platforms, mainly because advances in content analysis programs have reduced the time necessary to code what are often lengthy political texts. Moreover, increases in the reliability of such coding algorithms have the potential to replace laborintensive, expert-based coding with a highly reliable and more objective approach.

This article raises a cautionary note about the virtue of such methods. In a search for more reliable and less intensive methods, researchers need to be aware of the danger of placing too much faith in computer-based algorithms, which may lead to mistaken inferences about the ideological placement of political texts. Reliability may come at the expense of validity. If research produces counter-

Daniel Coffey is an assistant professor of political science at the University of Akron and a research fellow in the Ray C. Bliss Institute of Applied Politics. His research focuses on political parties, state politics, and political psychology. He is the co-editor (with John Green) of The State of the Parties (Rowman and Littlefield, 2011), and co-author of Buckeye Battlefield (University of Akron Press, forthcoming). He can be reached at dcoffey@uakron.edu. intuitive findings, it may be necessary to reevaluate the conventional wisdom, but researchers using highly automated text-coding programs need to pay close attention to the results and provide evidence that they correspond to external measures.

This article challenges a finding in this journal that American party platforms reveal only minor policy differences. I analyze the same question that Kidd explored-exactly how distinct are the policies and expressed beliefs of American parties?-by applying a more traditional coding technique to a different dataset on American state party platforms written between 2000 and 2004.

In contrast to Kidd's conclusion, this analysis produces three main findings. First, at the state level, party platforms reveal considerable ideological differences between the parties. Second, differences in state public opinion do not account for such ideological differences, which are instead more closely correlated with activist positions and increases in state party competition. As such, using a dataset with a significantly larger $N$ (121 observations for the two major parties to the total of six national party platforms for the two major parties-or 12, including the Green and Libertarian parties-used in Kidd's analysis), I find that American state parties are highly polarized on different measures.

More important, automated techniques are generally less concerned with the specific issues that are addressed in political texts. In particular, a focus on analyzing political texts ironically misses one of the key aspects of party platforms: content. As such, these 
techniques may overlook important indicators of the nature and degree of party conflict. I provide evidence that not only are parties ideologically polarized, but also that qualitative analysis of their platforms confirms that American parties are quite polarized indeed.

\section{A LACK OF DIFFERENCE?}

Recently, Kidd (2008) found that American political parties are not ideologically polarized, especially on domestic issues, by applying the "Wordscores" coding program to American national party platforms written between 1996 and 2004. Word scoring treats political texts as data; instead of operating as a single text, party platforms often contain thousands of words, with each word providing a data point that can be measured. Each word in a manifesto has a certain likelihood of appearing based on word frequencies derived from a reference text such as a previous expertcoded platform. Kidd provides a clear description of his methodology (see also Laver, Benoit, and Garry 2003; Martin and Vanberg 2008; Benoit and Laver 2008). In the aggregate, the distribution of words in a platform provides a highly reliable indicator of the ideology of the platform. Kidd confirms the conventional wisdom about American parties-that they are relatively moderate. He argues that Duncan Black's (1948) theory on policy convergence explains the absence of extremism: the parties have moderated their relative positions in response to their electoral fortunes in recent years.

The point of this study is not to challenge the reliability of the scoring technique, but to present an alternative method that demonstrates that American political parties are in fact quite polarized. A different approach for a different dataset produces a more valid result. Kidd's finding that American parties are similarly positioned on domestic issues is a puzzling contrast with most recent research, which finds-through a variety of different measurements, as Kidd himself notes-considerable ideological differences between the parties at the mass attitudinal level (Abramowitz and Saunders 2008; Hetherington 2001), in Congress (McCarty, Poole, and Rosenthal 2006), and among party activists (Layman and Carsey 2002).

Of course, the orthodox line about American parties is that their nonideological nature makes them distinct from other nations' parties, since their fragmented organizational structures cause them to focus more on winning elections and maintaining social cohesion than pushing dogmatic agendas (Epstein 1986). Some comparative studies, however, have found evidence for partisan differences. Klingemann, Hofferbert, and Budge (1994) find that American national party platforms are nearly as distinct from each other as many manifestos in European party systems. Gerring's (1998) extensive study of campaign speeches and national party platforms from 1828 to 1996 finds that American parties have distinct philosophies that are clearly articulated in national party platforms across decades.

\section{STATE PARTY PLATFORM POLARIZATION}

Using a technique that relies on a computer program (TEXTPACK) to assist with content analysis, I coded 121 state party platforms written between 2000 and 2004. In states where more than one platform was written between 2000 and 2004 for a state party, I created an average ideology score. Sentences were coded initially on the appearance of certain key words from an ideological dictionary. Because words have multiple meanings depending on the context, it was possible for sentences to be miscoded, so I manually reviewed every sentence in each platform. The gain in validity far outweighed the loss in the reliability (Coffey 2005). ${ }^{1}$

The procedure was fairly simple. Party ideology was calculated by the proportion of liberal and conservative sentences in each state of the state speech. Specifically, the calculation is:

$$
\text { (Liberal Sentences - Conservative Sentences) }
$$

(Total Number of Sentences in Platform)

By measuring ideology in this manner, a standardized value was assigned to each category, ranging from 1 (all liberal sentences) to -1 (all conservative sentences). The denominator was set as the total number of sentences in the platform, factoring moderate sentences into the ideological calculation and moving the score closer to o. For example, the 2002 Texas Democratic platform is 325 sentences long, of which 252 were determined to be liberal, 44 were determined to be conservative, and 29 were not coded. The corresponding score was .62.

This coding produced both valid and reliable results. Gerring defines party ideology as messages or positions that are "internally coherent, externally differentiated (from one another) and stable through time" $(1998,3)$. Using this framework, I coded as liberal those sentences that emphasized government intervention into economic markets for reasons such as protecting lower income citizens and spending more on social welfare programs. In addition, liberal sentences included statements of support for the protection and expansion of the rights of marginalized groups. Conservative sentences generally expressed opposition to governmental regulation, called for the protection of individual opportunity (especially through lower taxes and private property rights) in the marketplace, and advocated stricter regulation of individual behavior and a greater role for religion (often Christianity) in the public sector. If a sentence was ambiguous in its ideological position, it was not coded as ideological but was included in the denominator (total sentences). I used two basic guidelines to classify sentences: (1) Would such a sentence appear in the opposition party's platform? (2) How would a reasonable person interpret such a sentence?

The platforms clearly distinguish the parties across the states. The Democratic average score is a fairly liberal .68, while the average GOP platform is -.63. In fact, there is no overlap between the parties: Indiana's 2004 Republican platform, which is the most liberal GOP platform, has a score of -.15, while the 2002 Alabama Democratic platform, which is the most conservative Democratic platform, has a score of .42.

By comparing states in which both parties wrote platforms between 2000 and 2004, the manual coding found no overlap at all between party positions. Figure 1 provides stark evidence of the parties' polarization. The dot plot shows that rather than gravitating toward the center of the political spectrum, the state parties appear to push each other away toward the poles. To draw an analogy with physics, the ideological forces of parties in the American states are centrifugal, not centripetal. In fact, increased conservatism among state Republican platforms is associated with increased liberalism among state Democratic platforms $(r=-.45)$.

\section{THE MEDIAN VOTER THEOREM AND THE ACTIVISTS' MANIFESTO}

Kidd argues that his findings provide evidence for Downsian moderation-that is, parties are pulled to the center by the force 


\section{Figure 1}

\section{State Party Platform Polarization}

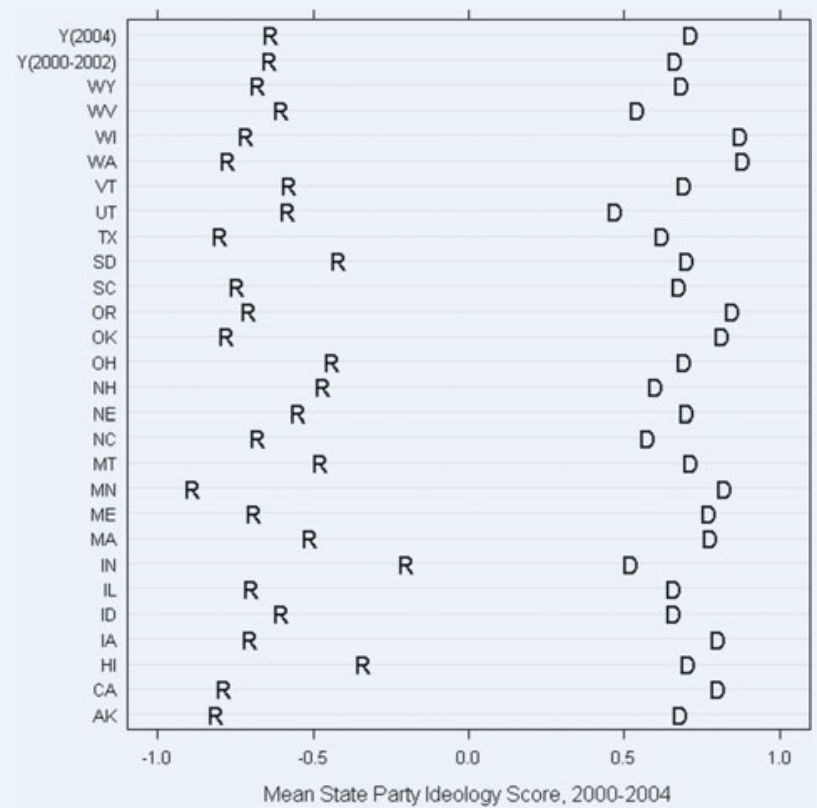

Note. Figure shows average platform ideology scores for states in which both state parties had platforms between 2000 and 2004. Platform scores range from -1 (most conservative) to 1 (most liberal).

of public opinion in a desire to maximize their chances for winning elections. Downsian moderation is, however, an empirical hypothesis, and so I tested whether median state public opinion explains the variance in state party platform ideology.

To test this relationship empirically, I modeled state party platform ideology as a function of several state-level variables that theoretically should explain the variance in party platform ideology. As Erickson, Wright, and McIver (1993; 2007) have shown, state median public opinion has a substantial impact on state legislators' ideology and the policy outputs of state governments. If Kidd is correct, party ideology should be related to median state opinion.

Alternatively, as Berry and Schildkraut have noted, since 1980, "regardless of motive, citizen groups work to accentuate the differences between the parties, to drive a wedge in further so that the parties do not gravitate toward a more moderate position" $(1998,148)$. Activists are the group most involved in the writing of the party platform (Jewell 1984; Pomper 2003). Even Fiorina, Abrams, and Pope (2005), who are skeptical of the degree of polarization in American politics, argue that the observed polarization of elected officials is largely a function of party activists, who push parties away from the opinions of the median voter. If the polarization view is correct, state party platforms should be shaped by party activist opinion. ${ }^{2}$

To test whether state party ideology is related to activist ideology or public opinion, I esti- mated two OLS models for platform ideology, one for each party. This approach allows for a greater sample size to include states in which only one party wrote a platform and was chosen because the factors that should affect platform ideology are measured at the state level. To measure public opinion, I used the updated Erikson, Wright, and McIver dataset that includes surveys of state public opinion from 1995 to $1999 .^{3}$ One benefit of these data is that their collection preceded the writing of the party platforms. For either party, state public opinion is not correlated with state party ideology. For the Democratic Party, a slight positive relationship exists $(r=.18)$, but the correlation is weak at best. For the Republican Party, the correlation $(r=.08)$ does not approach statistical significance.

To measure activist opinion, I used data from the Party Elite Studies of each party's national convention delegates between 1992 and 2004. ${ }^{4}$ Activist opinion was measured by the pooled average ideology of each state's party delegation for the four national party conventions from 1992 to 2004, creating a score ranging from 1.83 (the most liberal delegation) to 4.42 (the most conservative delegation). Activist ideology is more strongly correlated with party platform ideology for both Democratic platforms $(r=-.35, p=$ $.03)$ and Republican platforms $(r=-.29, p=.11)$ than with state public opinion (see figure 2).

I also included a variable for state party competition. In theory, party ideology should moderate with increases in party competition as parties moderate to avoid losing votes (Downs 1957). I measured party competition using the Ranney competition index, a measure that ranges from .50 , when there is no competition, to 1 , when the parties are perfectly competitive (Bibby and Holbrook 2004, 87). Finally, the model controls for state racial makeup (percent of African Americans) ${ }^{6}$ (see table 1).
Figure 2

\section{State Party Activist Ideology and Democratic Platform} Ideology

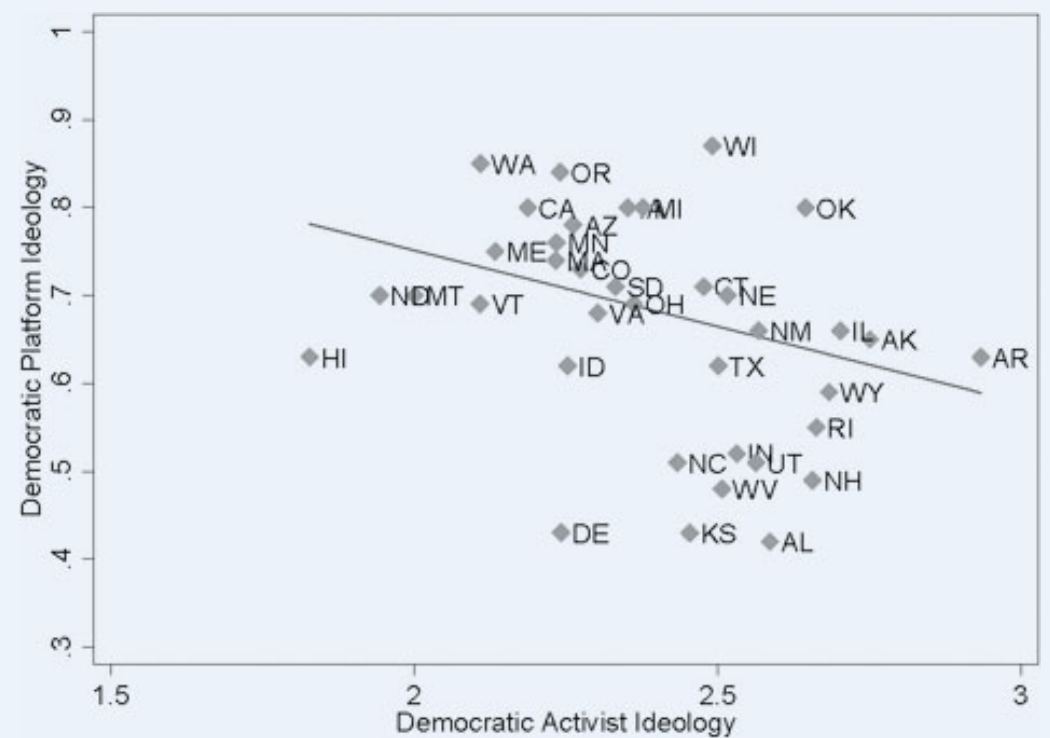

Note. Democratic Activist Ideology created from Party Elite Studies survey of each party's national convention delegates from 1992-2004. Activist opinion is measured by the pooled average ideology of each state's party delegation for the four national party conventions from 1992 to 2004 , creating a score that runs from 1.83 (most liberal delegation) to 4.42 (most conservative delegation). 
Table 1

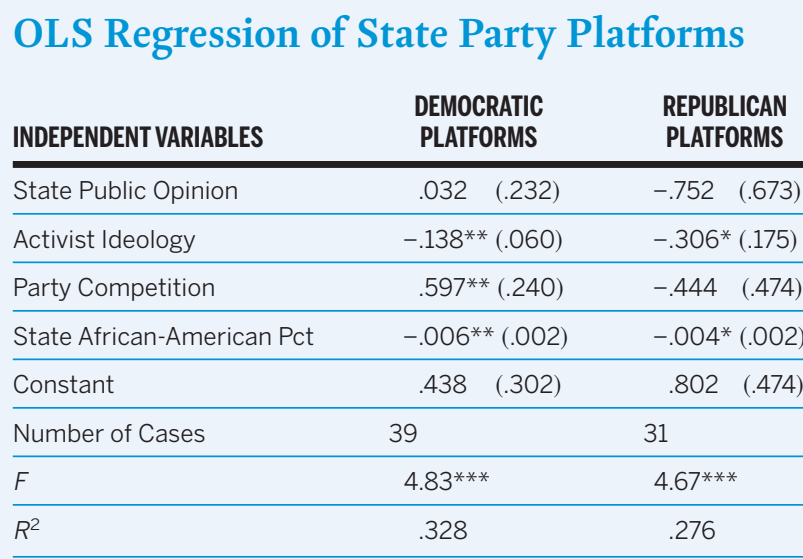

Note. Dependent variable is state party platform ideology. Coefficients are unstandarized OLS estimates using robust standard errors. ${ }^{*} p<.10 ;{ }^{* *} p<.05 ;{ }^{* * *} p<.01$.

The models show that state public opinion fares worse in explaining the variance in platform ideology than does state party activist opinion. In the Democratic model, state activist ideology is positive and significant, as expected, while public opinion is not significant. The percentage of African Americans is negative and significant, likely because most states with higher percentages of African Americans are located in the South, where the public and party activists tend to be more conservative. For the Republican platforms, activist ideology and the percentage of African Americans are significant at $p<.10$, with all coefficients in the expected direction and apparently leading to the same conclusions that can be drawn from the Democratic model.

Importantly, party competition is positively related to party ideology. The greater the level of party competition between the state parties, the more conservative the Republican platform becomes and the more liberal the Democratic platform becomes. In the same vein, many other scholars have attacked the median voter theorem in recent years (Lublin and Voss 2003; Hacker and Pierson 2005). While intuitively sound, the theory ignores differences in participation and information-gathering rates among the general public. Ideologically committed citizens are more likely to participate in politics and at earlier stages in the candidateselection and policymaking processes. Studies of legislative politics have found evidence for this counterintuitive hypothesis, which posits that an increase in competition at both the district and state legislative levels increases party-line voting in the legislature by making the party labels more salient (Aldrich and Battista 2002; Gulati 2004). It is also possible that the presence of an ideological alternative increases incentives for activists to become involved in party politics (Layman 2001; Carmines and Stimson 1989). In sum, then, empirical tests of the causes of state party platform differences indicate little support for Downs' or Black's theories but rather support the conclusions that (a) parties are polarized and $(b)$ polarization is increased by competition and activist ideology.

\section{THE IMPORTANCE OF ISSUES}

As Gerring (1998) argues, the study of ideas in both a quantitative and qualitative fashion is sorely lacking in political science. $\mathrm{He}$ argues that "any study of party ideologies is ... a study of what politics is all about. Since political parties are one of the chief disseminators of political culture, partisan rhetoric provides a window into the values and attitudes that have guided American politics" (21). One characteristic of the American party system is its relative decentralization, and the ability of state parties to write individual platforms allows them flexibility in position-taking. More intraparty diversity exists across states in terms of the mixture of issues that each party adopts than in overall ideology.

It is possible, then, that ideological measures may provide inaccurate portraits of party polarization, either over- or understating the degree of conflict that occurs between parties. Theories of "issue-ownership" or "issue salience" predict that party platforms should show little evidence of overlap on specific issues (Petrocik 1996). This hypothesis seems to be especially true in the context of European party conflict (Budge, Robertson, and Hearl 1990).

The evidence suggests that direct conflict is more common between state parties. Table 2 provides a few examples of direct challenges by each party on several issues. These statements provide voters with a clear sense of the parties' stance and general principles that voters could use to distinguish between them-a key standard for party responsibility, as defined by the authors of the 1950 APSA Report (American Political Science Association 1950).

Evidence also exists that parties will address the same issue in the same state. For example, the correlation for environmental issue content between opposing platforms within states is significant and positive. Wyoming Republicans devote $29 \%$ of platform sentences to environmental issues, while the Democrats devote $23 \%$. This pattern extends across issues: in New Hampshire, both parties reserve $14 \%$ of their platforms for education policy, while in Illinois, Democrats address health care in $13 \%$ of their platform compared to $9 \%$ of the Republican platform. ${ }^{7}$

I do not intend to claim that issue variation does not occur. Indeed, for Republicans, attention to social issues appears to be a clear marker of the extent to which the party is liberal or conservative. In platforms written between 2000 and 2002, liberal Republican parties avoided divisive social issues such as abortion, school prayer, and euthanasia. Of the five platforms with the most space reserved for abortion, the average ideology is -.73 ; for the five platforms that devote the least attention to abortion, the average ideology is a relatively moderate -.44 . Of the five with the most content devoted to economic development (23.34\%), the average ideology is -.44 , while those devoting the least attention to economic development $(4.05 \%)$ are more conservative, as indicated by an average ideological score of -.75 . Parties moderate by taking positions on different issues.

\section{REASONS FOR DIFFERENCES WITH KIDD}

A primary question resulting from this study is why my results differ so strongly from Kidd's analysis. There are both substantive and methodological reasons for this discrepancy. State party platforms are significantly shorter than national party platforms, with some using less than 1,00o words. A typical national party platform contains as many as 20,000 to 40,000 words, which may affect the results. The coding technique may also be responsible for some of the variance. In this study, sentences were coded as liberal, moderate, or conservative. Although I took pains to make sure that ambiguous or highly nuanced phrasings would be coded 
Table 2

\section{Examples of Direct Confrontation on Issues}

\begin{tabular}{|c|c|c|}
\hline $\begin{array}{l}\text { ISSUES } \\
\text { (STATE) }\end{array}$ & DEMOCRATS & REPUBLICANS \\
\hline Social Security (lowa) & $\begin{array}{l}\text { Maintaining a strong Social Security program including } \\
\text { survivor benefits. }\end{array}$ & We believe in the eventual privatization of Social Security. \\
\hline Health Care (Illinois) & $\begin{array}{l}\text { Democrats will continue to lead the charge for a Medicare } \\
\text { prescription drug benefit. Until that day, Illinois Democrats } \\
\text { will persist in their efforts, long frustrated by a Republican } \\
\text { controlled Senate, to provide relief for the high cost of } \\
\text { prescription drugs. }\end{array}$ & $\begin{array}{l}\text { Prescription drug costs can be controlled by reducing } \\
\text { regulation in distribution of the drugs and lobbying at the } \\
\text { federal level to make new drug approval more streamlined } \\
\text { as well as limiting the ability of foreign governments to } \\
\text { enact price controls. }\end{array}$ \\
\hline Abortion (Oklahoma) & $\begin{array}{l}\text { We affirm the right of a woman to make personal decisions } \\
\text { regarding reproductive matters as guided by individual } \\
\text { freedom of conscience and self-determination, and we } \\
\text { oppose any legislation that threatens that freedom for any } \\
\text { woman. }\end{array}$ & $\begin{array}{l}\text { We oppose abortion (including the use of RU- } 486 \text { and } \\
\text { partial birth abortion), infanticide, euthanasia and mercy } \\
\text { killings, and the funding of such by the government. }\end{array}$ \\
\hline Environment (Montana) & $\begin{array}{l}\text { The party supports the public ownership of fish, wildlife } \\
\text { streams and rivers of our state, and believes that the state } \\
\text { holds these resources in trust for the beneficial use of its } \\
\text { citizens. }\end{array}$ & $\begin{array}{l}\text { We strongly oppose the government policies that initiate } \\
\text { eco-system management as opposed to long recognized } \\
\text { multiple-use concepts of resource management and } \\
\text { stewardship. }\end{array}$ \\
\hline Education (Texas) & $\begin{array}{l}\text { Oppose any form of private school vouchers because } \\
\text { vouchers would drain resources essential to guarantee a } \\
\text { quality public education for all our children }\end{array}$ & $\begin{array}{l}\text { The Party encourages the Governor and the Texas } \\
\text { Legislature to enact legislation which establishes child } \\
\text { centered school funding options to bring about the } \\
\text { maximum freedom of choice in public, private or parochial } \\
\text { education if and only if a state constitutional amendment } \\
\text { that prohibits state regulations imposed on private and } \\
\text { parochial schools is first passed. }\end{array}$ \\
\hline Civil Rights (Minnesota) & $\begin{array}{l}\text { Repeal the Patriot Act. Repeal the Homeland Security Act } \\
\text { and prohibit any efforts by law enforcement agencies to } \\
\text { discriminately enforce laws on any ethnic and religious } \\
\text { groups or by socio-economic status. }\end{array}$ & $\begin{array}{l}\text { Strengthening our borders against the threat of terrorism } \\
\text { and stopping the flow of illegal immigrants, and deporting } \\
\text { illegal aliens. We are against amnesty for illegal aliens. We } \\
\text { oppose any program that will allow illegal aliens to remain in } \\
\text { the United States.... [We support] the extension of the } \\
\text { Patriot Act. }\end{array}$ \\
\hline
\end{tabular}

Source. 2000 and 2002 State Party Platforms.

as moderate, the coding method may have produced inflated ideological differences.

However, Weinberg's (2010) study also relied on Wordscores and found significant differences between Republican and Democratic governors in the language of state-of-the-state speeches, demonstrating that what he labels as "partisan signals" reflecting the ideological divide between the parties were driven by differences in the vocabularies of governors of different parties. It should be noted that Weinberg used national and selected state party platforms as his reference texts. In other words, my findings here are supported by additional research that also relies on the Wordscore methodology.

The use of third parties as a baseline is not clearly justified if third parties' language usage differs from that of the established parties. Weinberg (2010), among others, has found that Republicans and Democrats use simple words like pronouns very differently (e.g., Republicans tend to use "I", while Democrats use "our" or "we"). A lack of analysis of American third parties means that we do not have clear knowledge of how or why their pronoun or adjective choices are made. Certainly, the Wordscore technique has been shown to place party texts accurately in European party systems, so the use of minor parties is not in itself a problem. However, it is possible that automated coding programs work well because they can pick up on the use of an organically developed political language that expresses the terms of social disagreement in nations with more culturally entrenched third parties. In the
United States, it is not clear that the Green and Libertarian parties use language in a manner that clearly signals their ideological position relative to the language used by the two major parties. Consequently, placing them as ideological anchors may not be justified.

Alternatively, the differences between Kidd's findings and my own could be due to the unit of analysis used in each study. Many states in which party conflict has historically been nonideological did not write a party platform (Mayhew 1986). Thus, when party coalitions are brought together to write a single platform, it may be that the resulting platform is less distinctive from the platform of the opposition. Differences might also be process-generated. Many state party platforms, especially in caucus states, are written at the precinct level. Past research has shown that the probabilities of groups capturing state party organizations differ based on the structure of state parties (Usher 2000; Conger 2010). Social groups often politically target state party platform committees, and therefore, state party platforms are more likely to present highly polarized views on divisive issues

Yet it should be noted that the substantive differences in major parties' ideological positions are striking, as illustrated in the examples of direct conflict on a single issue. In many party platforms, as few as one or two sentences might be reasonably coded as running contrary to a party's ideology. The appearance of moderate sentences was rarely due to nuanced policy positions; rather, the coding reveals that moderation resulted from platforms that read 
more like campaign documents (such as those of the Indiana Republican Party) or lacked specific policy commitments.

\section{CONCLUSIONS AND DISCUSSION}

The use of automated content analysis programs clearly provides a significant leap forward in scholars' ability to code party platforms and political texts. There is little doubt that these techniques will become more commonly used and sophisticated over time. Researchers can now explore questions that were once prohibitively time-consuming. Yet, as tempting as automation may be, these techniques place a heavy burden on researchers to show the accuracy of the results in capturing the meaning of political texts and not simply producing the same score every time. The findings here aim to $(a)$ raise a cautionary note about the use of automated coding techniques and $(b)$ highlight the importance of examining the substance of platforms as a measure of party conflict.

One might claim that the findings here are outdated, since they rely on data from 2000 and 2004. On the other hand, my results are directly comparable to Kidd's, because they cover a
New York, Vermont, Washington, and New Mexico), which were chosen on the basis of party, regional, and demographic variation. The dictionary was occasionally modified to include new words that appeared when analyzing the platforms. Finally, two independent coders manually reviewed a $10 \%$ sample of the platforms, producing a $77 \%$ agreement for the coding of all sentences. See Coffey (2005) for a more detailed explanation.

2. Erikson, Wright, and McIver (1993) also find that party activists prevent elected officials from converging on the mean of state public opinion. Conservative activists pull elected Republican officials to the right and liberal activist pull elected Democrats to the left. From state to state, however, the center point between each party's set of activists is often very close to the ideological position of the state median vote, and thus, relative differences in activists' attitudes correlate with the variance in median public opinion from state to state. As a result, parties remain centered around median state public opinion in an almost perfect Downsian balance.

3. The updated dataset is available at http://sobek.colorado.edu/ $\sim$ mciverj/ wip.html.

4. The data for the Party Elite Studies (1992-2004) was made available by John Jackson and John Green.

5. The party competition measure takes into account the percentage of seats won by the parties in the state legislature, each party's percentage of the vote in gubernatorial elections, the frequency of divided government, and the length of time that the parties have controlled the governorship and the legislative houses.

6. Given the small sample sizes, the model was limited to only the variables included in table 1. Using demographic variables to predict platform ideology,

\section{Importantly, party competition is positively related to party ideology. The greater the level of party competition between the state parties, the more conservative the Republican platform becomes and the more liberal the Democratic platform becomes.... Studies of legislative politics have found evidence for this counterintuitive hypothesis, which posits that an increase in competition at both the district and state legislative levels increases party-line voting in the legislature by making the party labels more salient.}

time period at the core of his study (1996 to 2004). Moreover, although the sample sizes are small, the data are consistent with our theoretical expectations. I find that not only does the median voter theorem not explain party behavior, but that an opposite force seems to be at work, consistent with recent research on this theory's empirical validity. This article provides more evidence that the median voter theorem is more conditional than an absolute law in a two-party system.

Finally, the findings here point to the value of analyzing state party platforms, a task often overlooked by researchers. Greater variance exists at the state level, which can allow scholars to test a variety of hypotheses that are not testable by analyzing two platforms written every four years. The influence of public opinion, economic conditions, regional subcultures, population mobility, and other demographic trends, as well as institutional and legal differences in the structures of parties can be analyzed with more frequent state-level observations (since platforms are often written every two years). The federal nature of the American party system thus provides a way to incorporate new methods and test them in a more extensive fashion.

\section{NOTES}

I would like to thank John Jackson and John Green for providing access to the Party Elite Study data.

1. The dictionary was created using Laver and Garry's (2000) dictionary for British and Irish party manifestos and incorporating words appearing disproportionately in either the Republican or Democratic 1996 and 2000 party platforms and five selected gubernatorial state-of-the-state speeches from 2000 (Alabama, including state population density, turnout, and per capita income, resulted in models with smaller $R^{2}$ 's in which only the percentage of African Americans was related to party ideology for both Democratic and Republican platforms. As a result, state sociodemographics were estimated using only the percentage of African Americans.

7. Of 12 issues coded, the correlation was positive for eight issues for the 26 states in which both parties had a platform.

\section{REFERENCES}

Abramowitz, Alan I., and Kyle L. Saunders. 2008. "Is Polarization a Myth?” Journal of Politics 70: 542-55.

Aldrich, John H., and James S. Coleman Battista. 2002. "Conditional Party Government in the States." American Journal of Political Science 46: 164-72.

American Political Science Association. 1950. "Toward a More Responsible TwoParty System.” American Political Science Review 44 (3).

Benoit, Kenneth, and Michael Laver. 2008. "Compared to What? A Comment on 'A Robust Transformation Procedure for Interpreting Political Text' by Martin and Vanberg." Political Analysis 16: 101-11.

Berry, Jeffrey M., and Deborah Schildkraut. 1998. "Citizen Groups, Political Parties, and Electoral Coalitions." In Social Movements and American Political Institutions, ed. Anne N. Costain and Andrew S. McFarland, 136-56. New York: Rowman and Littlefield.

Bibby, John F., and Thomas M. Holbrook. 2004. "Parties and Elections." In Politics in the American States: A Comparative Analysis, 8th ed., ed. Virginia Gray and Russell L. Hanson. Washington, DC: CQ Press.

Black, Duncan. 1948. “On the Rationale of Group Decision Making.” Journal of Political Economy 56: 23-34.

Budge, Ian, David Robertson, and Derek Hearl, eds. 1990. Ideology, Strategy, and PartyChange: Spatial Analyses of Post-War Election Programmes in 19 Democracies. New York: Cambridge University Press.

Carmines, Edward G., and James A. Stimson. 1989. Issue Evolution: Race and the Transformation of American Politics. Princeton, NJ: Princeton University Press. 
Coffey, Daniel. 2005. "Measuring Gubernatorial Ideology: A Content Analysis of State of the State Speeches." State Politics and Policy Quarterly 5: 88-103.

Conger, Kimberly H. 2010. "Party Platforms and Party Coalitions: The Christian Right and State-Level Republicans." Party Politics 16: 651-68.

Downs, Anthony. 1957. An Economic Theory of Democracy. New York: Harper and Row.

Epstein, Leon. 1986. Political Parties in the American Mold. Madison: University of Wisconsin Press.

Erikson, Robert S., Gerald C. Wright, and John McIver. 1993. Statehouse Democ racy: Public Opinion and Policy in the American States. New York: Cambridge University Press.

- 2007. "Measuring the Public' Ideological Preferences in the 50 States: Survey Responses versus Roll Call Data." State Politics and Policy Quarterly 7 (2): 141-51.

Fiorina, Morris P., Samuel J. Abrams, and Jeremy C. Pope. 2005. Culture War? The Myth of a Polarized America. New York: Pearson Longman.

Gerring, John. 1998. Party Ideologies in America, 1828-1996. New York: Cambridge University Press.

Gulati, Girish J. 2004. "Revisiting the Link between Electoral Competition and Policy Extremism in the U.S. Congress.” American Politics Research 32: 495-520.

Hacker, Jacob S., and Paul Pierson. 2005. "Abandoning the Middle: The Bush Tax Cuts and the Limits of Democratic Control." Perspectives on Politics 3: 33-53.

Hetherington, M. J. 2001. "Resurgent Mass Partisanship: The Role of Elite Polarization." American Political Science Review 95: 619-32.

Jewell, Malcolm. 1984. Parties and Primaries: Nominating State Governors. New York: Praeger.

Kidd, Quentin. 2008. "The Real (Lack of) Difference between Republicans and Democrats: A Computer Word Score Analysis of Party Platforms, 1996-2004." PS: Political Science and Politics 41: 519-25.

Klingemann, Hans-Dieter, Richard I. Hofferbert, and Ian Budge. 1994. Parties, Policies, and Democracy. Boulder, CO: Westview Press.
Laver, Michael, Kenneth Benoit, and John Garry. 2003. "Extracting Policy Positions from Political Texts Using Words as Data." American Political Science Review 97: 311-31.

Laver, Michael, and John Garry. 20oo. "Estimating Policy Positions from Political Texts." American Journal of Political Science 44: 619-34.

Layman, Geoffrey C. 2001. The Great Divide: Religious and Cultural Conflict in American Party Politics. New York: Columbia University Press.

Layman, Geoffrey, and Thomas Carsey. 2002. "Party Polarization and 'Conflict Extension' in the American Electorate." American Journal of Political Science 46: 786-802.

Lublin, David, and D. Stephen Voss. 2003. "The Missing Middle: Why MedianVoter Theory Can't Save Democrats from Singing the Boll-Weevil Blues.” Jour nal of Politics 65: 227-37.

Martin, Lanny W., and George Vanberg. 2008. "A Robust Transformation Procedure for Interpreting Political Text." Political Analysis 16: 93-100.

Mayhew, David R. 1986. Placing Parties in American Politics: Organization, Electoral Settings, and Government Activity in the Twentieth Century. Princeton, NJ: Princeton University Press.

McCarty, Nolan, Keith T. Poole, and Howard Rosenthal. 2006. Polarized America: The Dance of Ideology and Unequal Riches. Cambridge, MA: MIT Press.

Petrocik, John R. 1996. "Issue Ownership in Presidential Elections, with a 1980 Case Study.” American Journal of Political Science 40: 825-50.

Pomper, Gerald. 2003. "Parliamentary Government in the United States: A New Regime for a New Century?" In The State of the Parties: The Changing Role of Contemporary Parties, 4 th ed., ed. John Clifford Green and Rick Farmer. New York: Rowman and Littlefield.

Usher, Douglas, 200o. "Strategy, Rules, and Participation: Issue Activists in Republican National Convention Delegations, 1976-1996." Political Research Quarterly 53: 887-903.

Weinberg, Micah. 2010. "Measuring Governors' Political Orientations Using Words as Data." State Politics and Policy Quarterly 10: 96-109. 


\section{CAMBRIDGE}

\section{JOURNALS}

The Documentary Record of United States Foreign Policy

\section{Foreign Policy Bulletin}

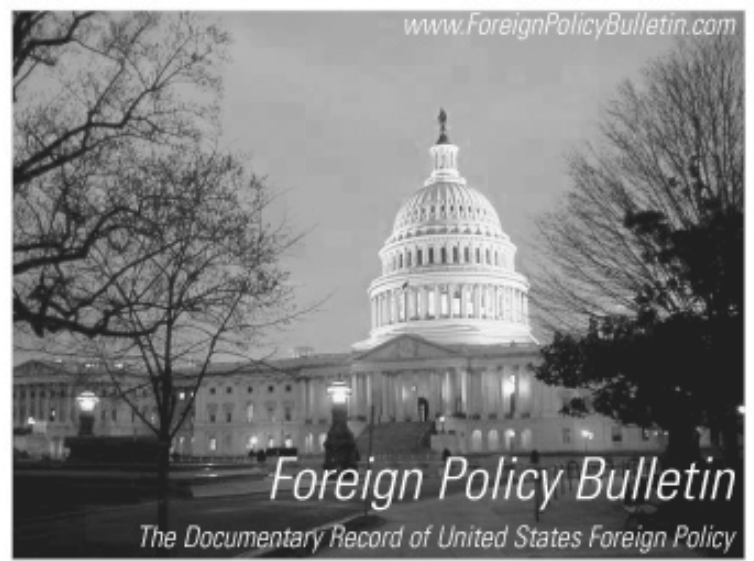

Volume 21 Issue 1, March 2011

Presidents Obama and Karzai Detail Plans to Fully Transition Security Responsibility to Afghan Security Forces by 2014

U.S. Administration Successfully Lobbies Congress to Ratify New START Treaty with Russia

Obama Announces U.S.-Indonesia Comprehensive Partnership

Anti-Counterfeiting Trade Agreement Talks Productive, Conclude with Breakthrough Treaty

CAMBRIDge UNIVERSITY PRESS

\section{Editor:}

Jack Goldstone

George Mason University

Foreign Policy Bulletin aims

to be the leading reference periodical for primary source documentation in American foreign policy and international affairs, by providing a timely, systematic record of United States foreign policy.

Unaffiliated with any government institution, this unique quarterly brings together major speeches, statements, public reports, and public remarks from U.S. officials; excerpts from Congressional debates; and relevant texts and reports from international organizations.

FRE E email alerts. Keep up-to-date with new material. Sign up at: journals.cambridge.org/fpb-alerts

Recommend Foreign Policy Bulletin directly from its homepage FRE online access for you when your library subscribes.

\section{journals.cambridge.org/fpb}

